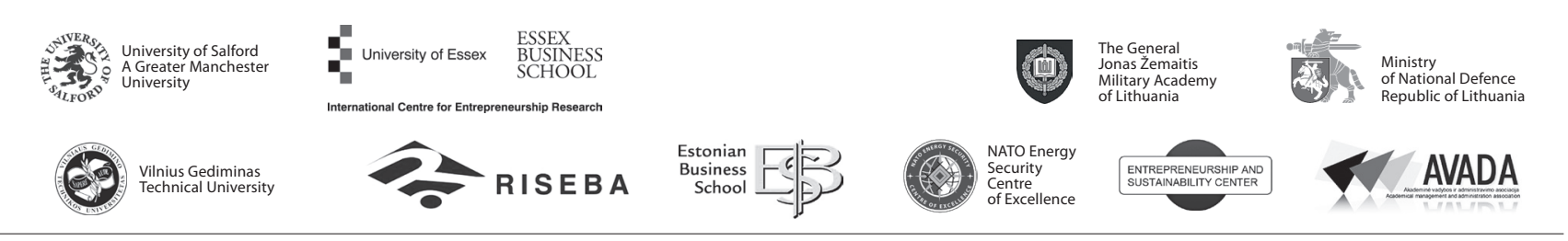

\author{
JOURNAL OF SECURITY AND SUSTAINABILITY ISSUES \\ ISSN 2029-7017 print/ISSN 2029-7025 online \\ 2018 March Volume 7 Number 3 \\ http://doi.org/10.9770/jssi.2018.7.3(18)
}

\title{
TOWARDS EFFICIENT POLICY MAKING: FORECASTS OF VULNERABILITY TO EXTERNAL GLOBAL THREATS
}

\author{
Manuela Tvaronavičiene $\dot{e}^{1,2}$ \\ ${ }^{1}$ Vilnius Gediminas Technical University, Saulètekio 11, LT-10223, Vilnius, Lithunia \\ ${ }^{2}$ The General Jonas Zemaitis Military Academy of Lithuania, Šilo g. 5A, LT-10322, Vilnius, Lithuania, \\ E-mail address: manuela.tvaronaviciene@vgtu.lt
}

Received 20 March 2017; accepted 15 December 2017

\begin{abstract}
Each country has to be able to develop efficient economic policy, facilitating sustainable economic development of national economy. In order to devise such policy, development patterns of a country has to be known, external threats indicated and various scenarios of their impact has to be foreseen, their impact forecasted and discussed. Alas, in contemporary environment in conditions of globalization predicting of development peculiarities and external factors' impact becomes especially urgent issue. Presented paper is devoted to discussion about predicted development selected national economies with account of threats caused by global environment. Economic indicators of Lithuania and Germany forested for period of three years, estimated, are being analyzed. The following methodology is applied. At first main macroeconomic indicators, such as real GDP growth, inflation, interest rates and unemployment ceteris paribus forecasted until year 2022 will be compared. The second, external threats will be selected and considered. Forecasted impact of indicated threats on real GDP growth of Lithuania and Germany will be discussed; source of employed data: database Passport, provided by Euromonitor International Company and powered by Clarivate Analytics (data are provided for research purposes for subscribed users). Change of real GDP growth in Lithuania and Germany under indicated threats pressure after one year period and three years period is juxtaposed. The findings suggest insights about development patterns of small comparatively less developed open economy and big well developed country belonging to the same economic union. Findings are instrumental for devising national economic policies enhancing resilience of national economies to external (global) threats.
\end{abstract}

Keywords: policymaking, national economic development, external threats, resilience, Lithuania, Germany

Reference to this paper should be made as follows: Tvaronavičienė, M. 2018. Towards efficient policy making: forecasts of vulnerability to external global threats, Journal of Security and Sustainability Issues 7(3): 591-600.

http://doi.org/10.9770/jssi.2018.7.3(18)

JEL Classifications: F01, F02

\section{Introduction}

There is a lot of attention paid to development issues of all countries, to be that countries of high development level, to be that countries of comparatively lower development countries, or the third countries, which still strive to achieve decent level of living offered by advanced developed countries (e.g. Pietrzak et al. 2017; Fabuš, 2017; Androniceanu, 2017; Sanusi, et al., 2017; Simionescu et al. 2017; Cheba \& Szopik-Depczyńska, 
2017; Kruk \& Waśniewska, 2017; Żelazny \& Pietrucha, 2017; Wójcik, 2017; Kisiała \& Suszyńska, 2017). Alas, there are no uniform efficient economic policies, which would be equally efficient to different countries due to their size, resources and abilities to exploit their potential, what ultimately is translated into productivity and international competitiveness (Sinicakova et al. 2017). In order to choose set of economic policy tools ad hoc for a selected country, it is necessary to foresee external threats and forecast their plausible impact (Kazandziska, 2016). Such prediction would allow to make hedging economic decisions in advance, what would ultimately allow to increase resilience of national economies to expected harm (Tkacova et al. 2017).

\section{Threats to sustainable development in recent literature}

Threats to national economies might be of very different character. Let us mention threats the most intensively discussed in the latest literate. One of recently tackled threats is cyber security, with wide range of facets such as: Internet and terrorism (Zeman et al. 2017); exploitation of social networks for various purposes (Šišulák 2017; Onyusheva, 2017; Szilágyi 2017), manipulation of voting (Limba et al. 2017), attack on institutions of critical importance (Štitilis et al. 2016; Korauš et al. 2017; Kordík, Kurilovská 2017). Another type of threat is lack energy security. Within that concern area the issues are related to energy availability (e.g. Lisin et al. 2017); affordability, consumption patterns, innovations in energy sector (Radwan, Sakr 2017) e.g. applicability of new technologies (Pechancová 2017; Zemlickiene et al. 2017), efficiency of energy use (e.g. Traversari et al. 2017; Kharlamova et al. 2016; Simionescu et al. 2017). Besides cyber insecurity and energy insecurity, or, actually, threats, which are the mostly emphasized in the resent literature, there are external threats related to terrorism and migrants, which affect big part of our planet (Beinoravičius, Vainiute 2017; Lincényi 2017; Walancik and Chmiel, 2014). Indicated threats are of international character, related to technologies, like cyber security and political/economical/technological/sociological, such energy security.

There is no doubt that myriad of other threats of different character could be found besides those, which we listed as the most discussed recently. In our research we will concentrate on another set of threats, which are related to crises in other countries and whole regions, or political decisions, which, as expected, would affect economies of other countries (Štiglic 2017; Belás et al. 2017).

\section{Forecast of main economic indicators in selected countries: local scenarios}

In our research we are going to juxtapose forecasted development of two differently developed European countries: Lithuania and Germany. Those countries may seem incompatible from the first glance, since Lithuania is small open economy, and Germany is one of leading European country with one of the best developed economies in European Union. The purpose of choosing such different countries for juxtaposing is to be grounded in the following way.

Research question is, how much development path differs of countries of different economic performance belonging to same economic union. Would mid-term forecasting hinted on economic convergence tendencies, what is natural economic expectation.

Research design and methodology. The following methodology is applied. At first main macroeconomic indicators, such as real GDP growth, inflation, interest rates and unemployment ceteris paribus forecasted until year 2022 will be compared. The second, external threats will be selected and considered. Forecasted impact of indicated threats on real GDP growth of Lithuania and Germany will be discussed; source of employed data: database Passport, provided by Euromonitor International Company and powered by Clarivate Analytics (data are provided for research purposes for subscribed users). Change of real GDP growth in Lithuania and Germany under indicated threats pressure after one year period and three years period is juxtaposed. The findings suggest insights about development patterns of small comparatively less developed open economy and big well developed country belonging to the same economic union (Becerra-Alonso et al., 2016). Findings is expected to be instrumental for devising national economic policies enhancing resilience of national economies to external (global) threats. 


\section{Comparison of main macroeconomic indicators ceteris paribus forecasted until year 2022 for Lithuania and Germany}

Below main macroeconomic indicators - real GDP growth, unemployment rate, inflation and interest rate for Lithuania until year 2022 are presented. Forecasting is retrieved from database of Euromonitor International, Passport, powered by Clarivate Analytics.

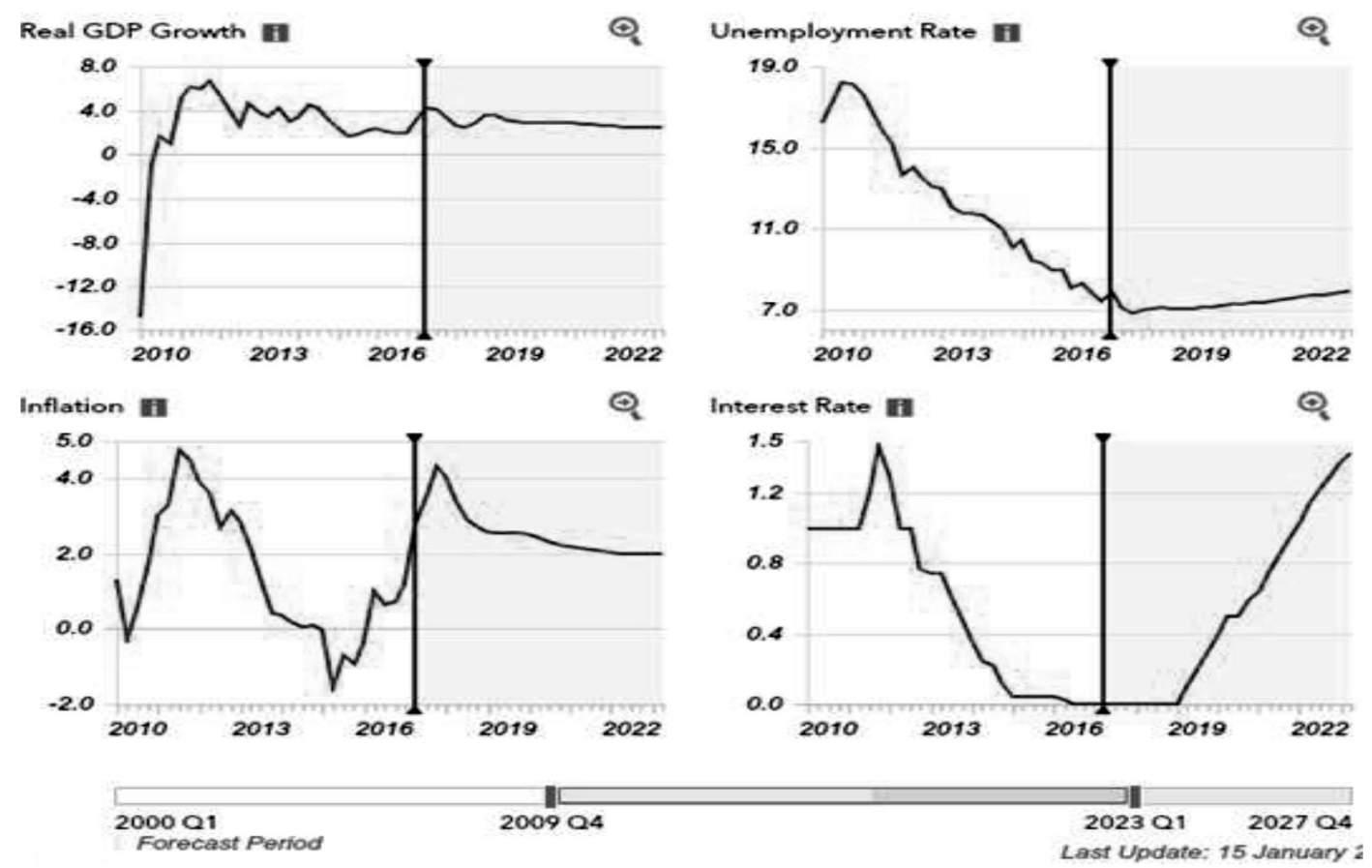

Fig. 1. Main macroeconomic indicators forecasted for Lithuania until year 2022.

Source: Passport database

Forecasted economic indicators can be commented in the following way. Real GDP growth is above 2 percent, inflation is nearing to 2 percent and interest rate reaches estimated 1,4 percent in year 2022 . The provided forecasted values of the main three indicators would signal about health of Lithuanian of economy. Alas, the fourth indicator, specifically, unemployment rate, which is above 7 percent in year 2022 signals that economy still needs considerable restructuring for achieving sustainable economic growth. To generalize, the high forecasted unemployment rate does not allow to evaluate overall economic perspective as positive.

Let us overview prospects of economic of Germany. Analogic forecasted data is presented below in Figure 2. 


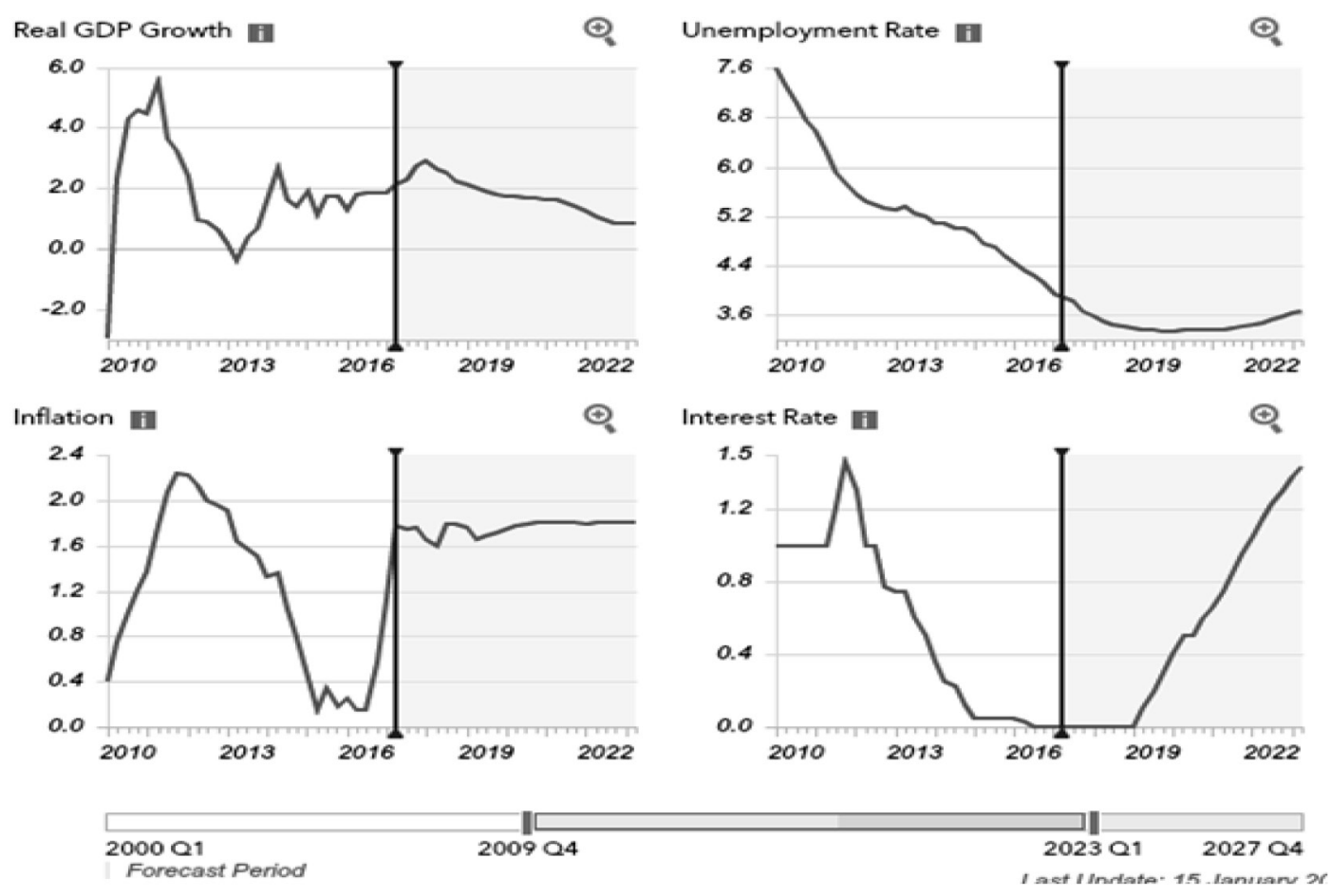

Fig. 2. Main macroeconomic indicators forecasted for Germany until year 2022.

Source: Passport database

Forecasted change of main economic indicators for Germany is as follows: real GDP growth rate in year 2022 is expected to be estimated 1 percent, inflation around 1,5 percent, interest rate around 1,4 percent in year 2022. The fourth indicator, unemployment rate, is forecasted to be approximately 3,6 percent in year 2022 .

Juxtaposing of forecasted data for Lithuania and Germany allows us to reveal similarities and differences of the development of the selected countries. Comparative similarities could be found in rather similar modes of real GDP growth rate (in Lithuania 2 percent, in Germany, respectively, 1 percent), inflation rate (in Lithuania 2 percent, in Germany, respectively, 1,5 percent) and interest rates (1,4 percent in both countries). The forecasted indicators are not identical, but rather near (except for real GDP growth, which for Lithuania is faster ( 2 percent versus 1 percent in Germany). Despite this numerical difference in real GDP growth, the difference judging from economic point of view is not substantial, since, as economic theory suggest, real GDP growth 1-2,5 percent signal about stability of economic growth at considered period of economic cycle (e.g. 3 years, as in our case may coincide with part of economic cycle, which is characterized by upper part of inverted U shape of the cycle). To wrap up, real GDP growth rate, inflation rate and interest rate, forecasted for Lithuania and Germany until year 2022 signal about rather similar path of development of selected countries. Now let us stop on differences. Unemployment rate, forecasted for Lithuania is 7 percent, while, respectively, for Germany this indicator is only 3,6 percent. We can provide economic interpretation for received difference: Lithuania, as it is expected, still would develop under conditions of intensive economic restructuring, what would cause high level of unemployment. Need for economic restructuring is the main difference, which characterized development path of national economies of Lithuania and Germany.

\section{Forecasts of vulnerability to external threats: Lithuania versus Germany}

There are various types of threats and insecurities, which can impact development of countries. The threats, which are widely discussed in the latest literature, e.g. cyber security, energy security, migrant crisis, terrorism are commented in the introduction part of this paper. Here we want to point out, that there are a lot of threats of different character, which may impact economic development of any countries, which are comparatively less elaborated in economic literature. Those threats, as it is provided in Euromonitor database Passport, powered 
by Clarivate Analytis are (not all indicate threats are provided here): Advanced Economies Stagnation (AE Stagnation), Emerging Markets Slowdown (EM Slowdown), Emerging Markets Slowdown (EM Slowdown), Eurozone Recession Scenario, Global Crisis Scenario, Eurozone Debt Crisis Scenario, No-Deal Brexit, Latin American Stagnation Scenario (LA Stagnation), Trump Trade War, China Hard Landing Scenario, Trump Adverse Policies, Light Brexit (Euromonitor International, Passport).

Below impact of some major threats on Lithuanian economy is presented. Lithuanian economy is represented by indicator of real GDP growth; Figure 3 reflects impact of threat factors after one year of pressure, and Figure 4 reflects the effect of selected threat factors after 3 years of pressure. Description of impacting threats is provided below Figure 3.

\section{Macro Model}

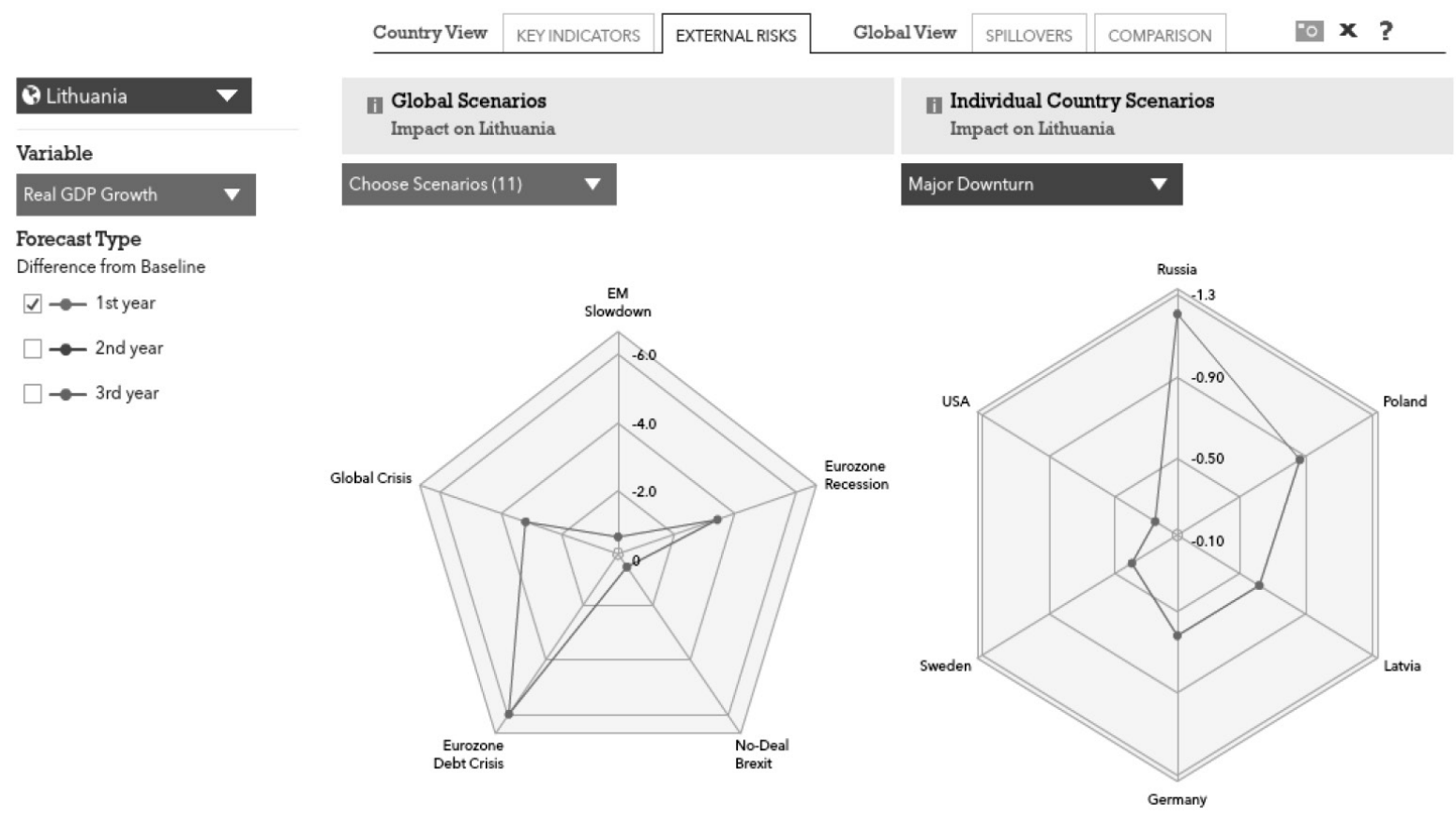

Fig. 3. Impact of selected threat factors on Lithuanian economics, estimated in Real GDP growth, after one year of pressure (on the right) and impact of downturn in related economies on economy of Lithuania (on the left)

Description of threat factors (source: Euromonitor International, Passport):

Emerging Markets Slowdown (EM Slowdown). Scenario assumptions: long term potential output in emerging markets lower than expected; domestic business and consumer confidence drop significantly; increase in capital outflows leads to higher financing costs. Estimated probability: 8-13\% over a one-year horizon, $15-25 \%$ over a two-year horizon.

Eurozone Recession Scenario. Scenario assumptions: growing geopolitical and eu break-up risks increase uncertainty and reduce investment; significant deterioration in Eurozone credit markets, consumer confidence and business confidence. Estimated probability: 4-9\% probability over a one-year horizon, 8-18\% over a twoyear horizon.

No-Deal Brexit. Scenario assumptions: negotiations between the EU and the UK break down, and the UK leaves the EU in 2019 without reaching a trade agreement, trade relations with the EU default to World Trade Organisation (WTO) conditions; heightened uncertainty and lower labour productivity lead to a long-term decline in UK real GDP of around 3\% relative to the baseline forecast. Estimated Probability: 35-45\%. 
Eurozone Debt Crisis Scenario. Scenario assumptions: growing geopolitical and EU break-up risks increase uncertainty and reduce investment; renewed tensions in Italian and Spanish sovereign debt markets cause turmoil in financial markets; collapse in business and consumer confidence. Estimated probability: 0-4\% probability over a 1-year horizon, $0-8 \%$ over a 2-year horizon.

Global Crisis Scenario. Scenario assumptions: advanced economies stagnate, with annual potential output growth declining by 1-1.5 percentage points below the baseline forecast; long-term potential growth in emerging markets is significantly below expectations, leading to reduced private sector confidence and higher country borrowing costs; a rise in the proportion of distressed loans leads to a financial crisis in China; greater pessimism about Eurozone growth prospects lead to lower private sector spending and a deterioration in Eurozone credit markets. Estimated probability: 1-5\% over a 1-year horizon, 2-10\% over a 2-year horizon.

Interpretation of obtained results (left side of Figure 3). Eurozone Debt Crisis Scenario would hit Lithuanian economy after one year of pressure considerably: its' real GDP growth would be diminished by 8 percent. This scenario's probability is low: $0-4 \%$ probability over a 1 -year horizon, $0-8 \%$ over a 2 -year horizon. Global Crisis Scenario appears to be the second major threat, which would harm real GDP growth by estimated 3,7 percent. Probability of this scenario is slightly higher, but still rather low: 1-5\% over a 1-year horizon, $2-10 \%$ over a 2-year horizon. Eurozone Recession Scenario would deteriorate Lithuanian real GDP growth by estimated 3,6 percent; this scenario's probability is 4-9\% over a one-year horizon, $8-18 \%$ over a two-year horizon. No-Deal Brexit would affect Lithuanian economy inconsiderably; probability of this scenario is $35-45 \%$.

To conclude, Eurozone Recession Scenario is the most dangerous for Lithuanian economy out of all threats discussed above, it would deteriorate Lithuanian economy considerably after one year of impact.

On the right side of Figure 3 impacts on Lithuanian real GDP growth of major downturn in related countries are presented. Major downturn in Russia and Poland would affect Lithuanian economy the most.

Let us look at the impact of the listed threats on Lithuanian real GDP growth in three years period (Figure 4).

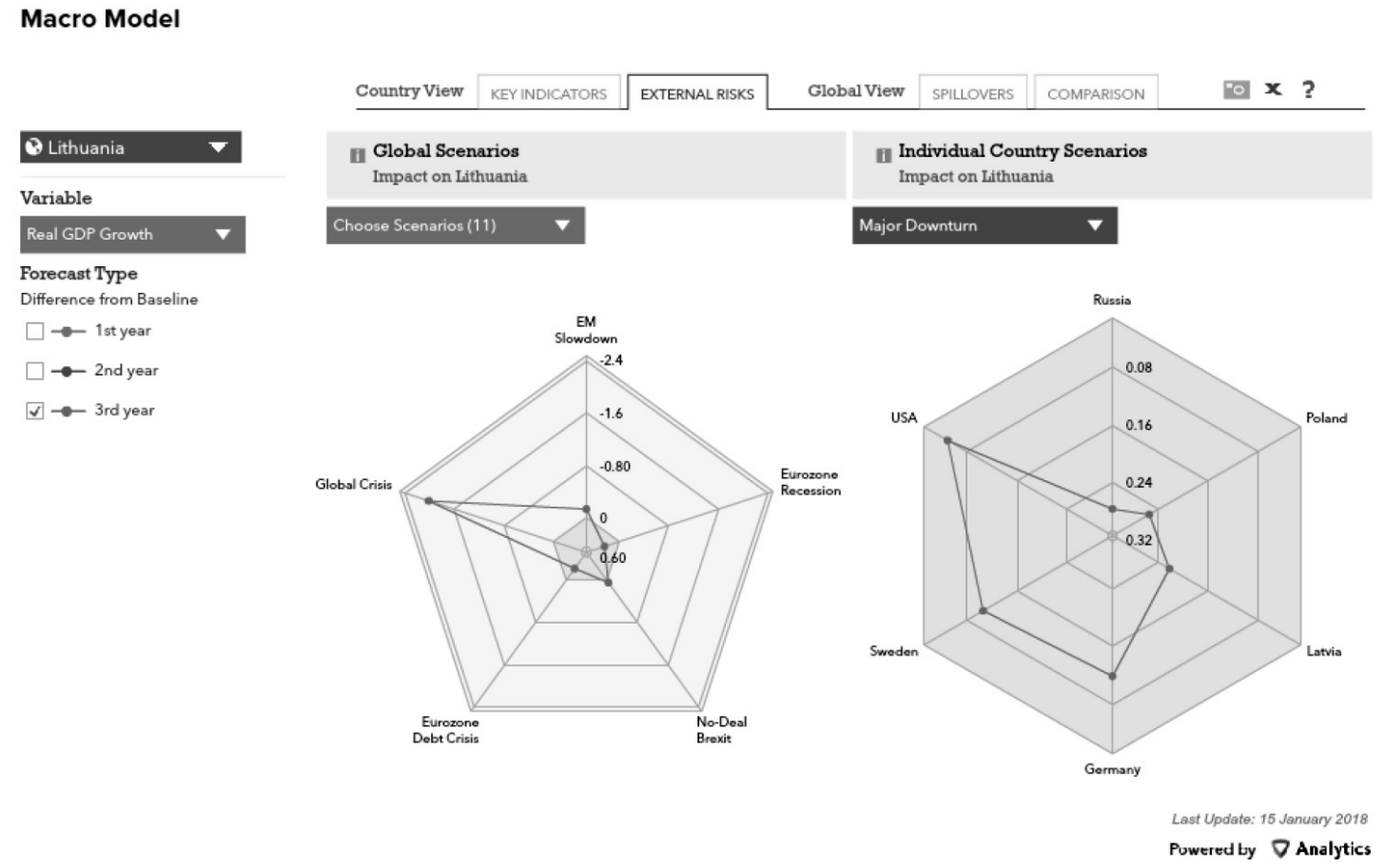

Fig. 4. Impact of selected threat factors on Lithuanian economics, estimated in Real GDP growth, after three years of pressure (on the right) and impact of downturn in related economies on economy of Lithuania (on the left) 
Let us analyze Germany's real GDP growth resilience to the enhanced set of threats in one and three years of their impact (Figure 5).

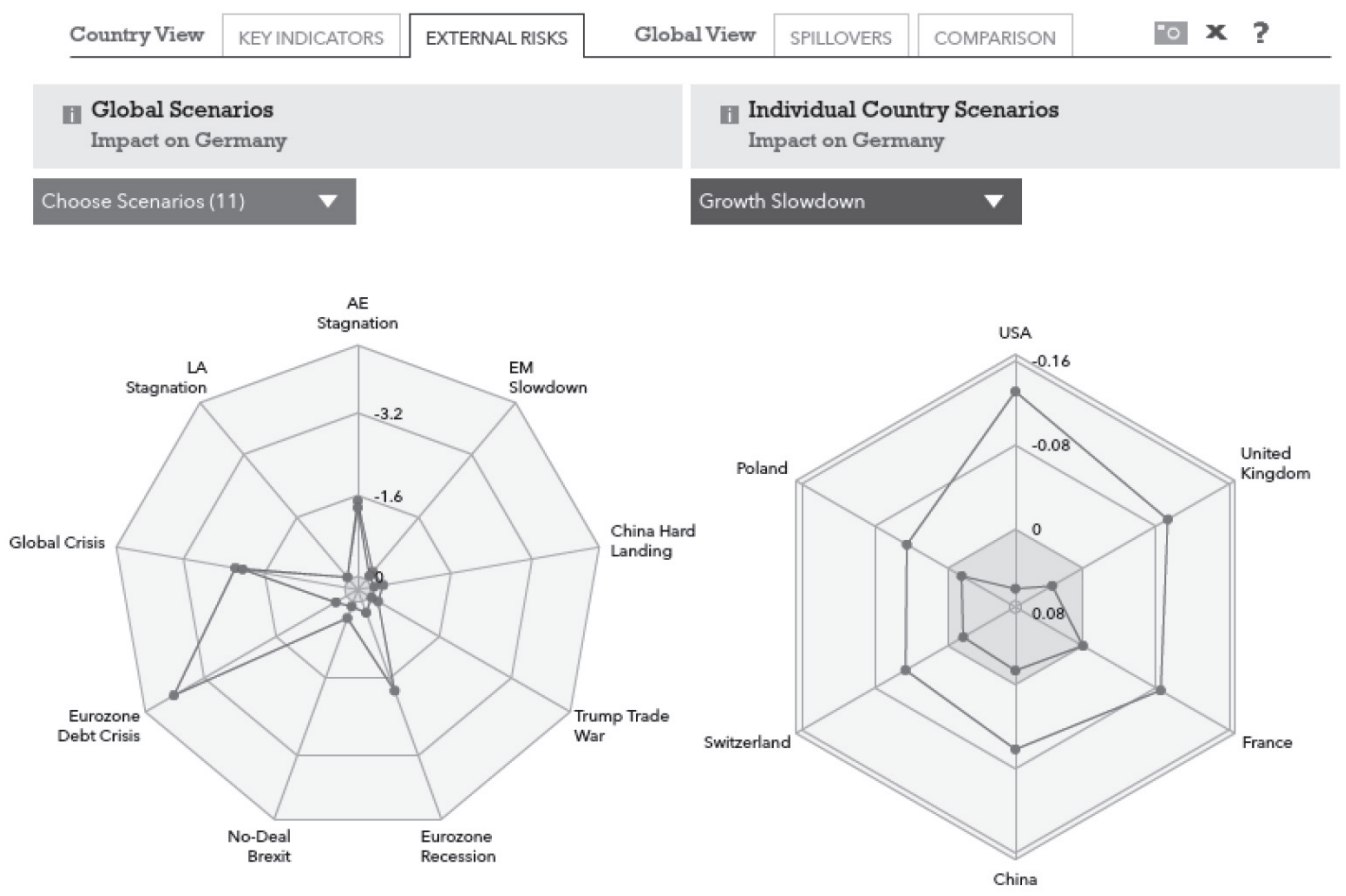

Fig. 5. Impact of selected threat factors on Germany's economics, estimated in Real GDP growth, one year (after in blue color) and three years of pressure (in red color; look at the right side of the figure), and impact of downturn in related economies on economy of Germany (look at the left of the figure)

Description of additionally added threat factors (source: Euromonitor International, Passport)

Description of additional threat factors, included into German read GDP forecasting (source: Euromonitor International, Passport):

Advanced Economies Stagnation (AE Stagnation). Scenario assumptions: growing influence of populist politicians leads to rising trade and immigration restrictions, and a slowdown in implementation of structural reforms; annual labour productivity growth in advanced economies over the next five years declines significantly below the baseline forecast; greater private sector pessimism about the future reduces business investment and consumer spending; the average annual GDP growth in advanced economies declines by 1.2-1.5 percentage points relative to the baseline forecast over a five-year horizon. Estimated probability: $8-13 \%$ over a one-year horizon, $15-25 \%$ over a two-year horizon.

Latin American Stagnation Scenario (LA Stagnation). Scenario assumptions: current combination of low commodity prices, lack of structural reforms and pessimism about future growth in Latin America gets entrenched; investment and productivity growth decline much more strongly than in the baseline forecast. Estimated probability: 0-10\% over a 1-year horizon.

Trump Trade War. Scenario assumptions; the US imposes a $45 \%$ tariff on Chinese imports and a $15-20 \%$ tariff on imports from other Asian countries; the US drops out of NAFTA and imposes a $35 \%$ tariff on Mexican imports; Asian Countries and Mexico retaliate with tariff increases on the US. Estimated probability: 4-9\% over a one-year horizon, 8-17\% over a two-year horizon.

China Hard Landing Scenario. Scenario assumptions: a rise in the proportion of non-performing loans leads to a banking crisis and tightening credit conditions; private sector confidence declines, slowing down the rebalancing process; delays in the structural reforms process reduce China's long term GDP. Estimated probability: $4-14 \%$ over a one-year horizon, $8-26 \%$ over a two-year horizon 
Trump Adverse Policies. Scenario assumptions: the US imposes a 45\% tariff on Chinese imports, a $15-20 \%$ tariff on imports from other Asian countries and a 35\% tariff on Mexican imports, leading to a trade war; large expulsions of illegal migrant workers and stricter immigration restrictions reduce labour supply; greater concerns about US government deficits and a reversal in stock market optimism lead to significant interest rate increases and declining stock market prices. Estimated Probability: 2-6\% over a 1-year horizon, 4-12\% probability over a 2-year horizon.

The forecasted impacts of external threats to national economy of Germany estimated in real GDP growth after one year and, respectively, three years of impact indicate, that Germany is the most vulnerable to Eurozone Debt Crisis and Global Crisis. This impact is rather high after one year of pressure. What is peculiar, that after three years this impact diminishes, what means that Germany's economy manages to resist to external treats rather efficiently. It has to be mentioned that that such threat as no-deal Brexit, does not have more significant impact on economy on Germany, neither in one, nor in three years. Impact of downturn of related countries is very low for Germany‘s economy.

If to juxtapose Lithuanian and Germany's case, it has be stated that despite Lithuania's performance in three years will remain worse because of high unemployment, its resilience to external threats inconsiderably lags behind if to compare with resilience to economy of Germany.

\section{Conclusions}

Obtained results allowed us reveal peculiarities of development two different countries belonging to European Union. Lithuania, small open economy, most likely, will develop stably during next four years, alas, unemployment rate will remain high (ceteris paribus). If to admit that Lithuania would be impacted by external global threats, then impact of Eurozone Recession Scenario affected Lithuanian economy the most out of all threats in one year of pressure; in three year the impact were neutralized. Impact slowdown of performance of related economies would not impact Lithuanian economy considerably. Germanys' economy develop more stably, alas real GDP growth would be slow. Germany's economy is vulnerable to Eurozone debt crisis, its impact would be neutralized in 3 years. Both, Lithuania and Germany is resilient to Brexit impact. Obtained results allow to elaborate respective economic policies hedging the considered countries from predicted consequences of revealed impacts of considered threats.

\section{Study limitations and further discussions}

Each forecasting has its limitations, since it is impossible to foresee impact all affecting factors on considered phenomenon. Further discussion could reveal what probability is of arising of other threats, not taken into account in this research.

\section{References}

Androniceanu, A. (2017). The three-dimensional approach of Total Quality Management, an essential strategic option for business excellence, Amfiteatru Economic, 19(44), 61-78.

Becerra-Alonso, D., Androniceanu, A., Georgescu, I., (2016). Sensitivity and vulnerability of European countries in time of crisis based on a new approach to data clustering and curvilinear analysis. Administratie si Management Public, (27), 46-61.

Beinoravičius, D., Vainiute, M. (2017). 'The management of terrorism roots as a prerequisite for successful fight against terrorism', Journal of Security and Sustainability Issues, 7(2), 193-202. https://doi.org/10.9770/jssi.2017.7.2(2)

Belás, J.; Mišanková, M.; Schönfeld, J.; Gavurova, B. (2017). 'Credit risk management: financial safety and sustainability aspects', Journal of Security and Sustainability Issues, 7(1), 79-93. https://doi.org/10.9770/jssi.2017.7.1(7)

Cheba, K., \& Szopik-Depczyńska, K. (2017). 'Multidimensional comparative analysis of the competitive capacity of the European Union countries and geographical regions', Oeconomia Copernicana, 8(4), 487-504. https://doi.org/10.24136/oc.v8i4.30

Czech, A. (2017). 'Economic dimension of Polish energy security’. Oeconomia Copernicana, 8(3), 383-399. https://doi.org/10.24136/ 
oc.v8i3.24

Fabuš, M. (2017). 'Current development of business environment in Slovakia and Czech Republic', Entrepreneurship and Sustainability Issues 5(1): 127-137. https://doi.org/10.9770/jesi.2017.5.1(10)

Fabuš, M. (2017). 'Current development of business environment in Slovakia and Czech Republic', Entrepreneurship and Sustainability Issues, 5(1), 127-137. https://doi.org/10.9770/jesi.2017.5.1(10)

Kazandziska, M. K. (2016). 'Macroeconomic policy regime in Poland'. Equilibrium. Quarterly Journal of Economics and Economic Policy, 11(3), 411-436. https://doi.org/https://doi.org/10.12775/EQUIL.2016.019

Kharlamova G., Nate S., Chernyak O. (2016), 'Renewable energy and security for Ukraine: challenge or smart way?', Journal of International Studies, Vol. 9, No 1, pp. 88-115. https://doi.org/10.14254/2071-8330.2016/9-1/7

Kisiała, W., \& Suszyńska, K. (2017). 'Economic growth and disparities: an empirical analysis for the Central and Eastern European countries'. Equilibrium. Quarterly Journal of Economics and Economic Policy, 12(4), 613-631. https://doi.org/10.24136/eq.v12i4.32

Korauš, A.; Dobrovič, J.; Rajnoha, R.; Brezina, I. (2017). 'The safety risks related to bank cards and cyber attacks', Journal of Security and Sustainability Issues, 6(4), 563-574. https://doi.org/10.9770/jssi.2017.6.4(3)

Kordík, M. and Kurilovská, L. (2017). 'Protection of the national financial system from the money laundering and terrorism financing‘, Entrepreneurship and Sustainability Issues, 5(2), 243-262. https://doi.org/10.9770/jesi.2017.5.2(7)

Kruk, H., \& Waśniewska, A. (2017). 'Application of the Perkal method for assessing competitiveness of the countries of Central and Eastern Europe‘, Oeconomia Copernicana, 8(3), 337-352. https://doi.org/10.24136/oc.v8i3.21

Limba, T.; Agafonov, K.; Paukštè, L.; Damkus, M.; Plèta, T. (2017). 'Peculiarities of cyber security management in the process of internet voting implementation', Entrepreneurship and Sustainability Issues, 5(2), 368-402. https://doi.org/10.9770/jesi.2017.5.2(15)

Lincényi, M. (2017). 'Entrepreneurship ecosystem facets: the European migrant crisis and public opinion in Slovakia', Entrepreneurship and Sustainability Issues, 5(2), 357-367. https://doi.org/10.9770/jesi.2017.5.2(14)

Lincényi, M.; Fabuš, M. (2017). 'Economic trends of business actors on daily newspaper market: case of the Slovak Republic', Entrepreneurship and Sustainability Issues, 5(1), 91-104. https://doi.org/10.9770/jesi.2017.5.1(7)

Lisin, E.; Kindra, V.; Horváthová, Z. (2017). 'Sustainable development of regional heat supply systems in the context of the Eurasian economic union energy markets association', Journal of Security and Sustainability Issues, 6(4), 745-760. https://doi.org/10.9770/ jssi.2017.6.4(18)

Niño-Amézquita, J.; Legotin, F.; Barbakov, O. (2017). 'Economic success and sustainability in pharmaceutical sector: a case of Indian SMEs', Entrepreneurship and Sustainability Issues, 5(1), 157-168. https://doi.org/10.9770/jesi.2017.5.1(13)

Onyusheva, I. (2017) Analytical and managerial issues of human capital in conditions of global competitiveness: The case of Kazakhstan. Polish Journal of Management Studies, 16 (2), pp. 198-209.

Passport [Online]. Euromonitor International [2018, February 10] Available: https://www.portal.euromonitor.com/portal/magazine/ homemain

Pechancová, V. (2017). 'Renewable energy potential in the automotive sector: Czech regional case study', Journal of Security and Sustainability Issues, 6(4), 567-545. https://doi.org/10.9770/jssi.2017.6.4(1)

Pietrzak, M. B.; Balcerzak, A. P.; Gajdos, A.; Arendt, L. (2017). 'Entrepreneurial environment at regional level: the case of Polish path towards sustainable socio-economic development', Entrepreneurship and Sustainability Issues, 5(2), 190-203. https://doi.org/10.9770/ jesi.2017.5.2(2)

Radwan, A. and Sakr, MM. (2017). 'Review of Egypt Science and Technology System: SWOT analysis', Entrepreneurship and Sustainability Issues, 5(2), 204-211. https://doi.org/10.9770/jesi.2017.5.2(3)

Sanusi, K.A., Meyer, D., Ślusarczyk, B. (2017) The relationship between changes in inflation and financial development. Polish Journal of Management Studies, 16 (2), pp. 253-265.

Simionescu, M., Albu, L. L., Raileanu Szeles, M., \& Bilan, Y. (2017). 'The impact of biofuels utilisation in transport on the sustainable development in the European Union', Technological and Economic Development of Economy, 23(4), 667-686.

Simionescu, M.; Lazányi, K.; Sopková, G.; Dobeš, K.; Balcerzak, A. P. (2017). 'Determinants of Economic Growth in V4 Countries and 
Romania‘ Journal of Competitiveness, Vol. 9, Issue 1, pp. 103 - 116. DOI: 10.7441/joc.2017.01.07

Sinicakova, M.; Sulikova, V.; Gavurova, B. (2017). 'Twin Deficits Threat in the European Union', E \& M Ekonomie a Management, 20(1), 144-156. https://doi.org/10.15240/tul/001/2017-1-010

Šišulák, S. (2017). 'Userfocus - tool for criminality control of social networks at both the local and international level', Entrepreneurship and Sustainability Issues, 5(2), 297-314. https://doi.org/10.9770/jesi.2017.5.2(10)

Štiglic, D. (2017). 'Towards security through economic policy: a Baldwin's approach', Journal of Security and Sustainability Issues, 7(1), 55-65. https://doi.org/10.9770/jssi.2017.7.1(6)

Štitilis, D.; Pakutinskas, P.; Malinauskaitè, I. (2016). 'Preconditions of sustainable ecosystem: cyber security policy and strategies', Entrepreneurship and Sustainability Issues, 4(2), 174-182. https://doi.org/10.9770/jesi.2016.4.2(5)

Szilágyi, G. A. (2017). 'Exploration Knowledge Sharing Networks Using Social Network Analysis Methods'. Economics and Sociology, 10(3), 179-191. doi:10.14254/2071-789X.2017/10-3/13

Tkacova, A.; Gavurova, B.; Behun, M. (2017). 'The Composite Leading Indicator for German Business Cycle', Journal of Competitiveness, Vol. 9, Issue 4, pp. 114-133. DOI: 10.7441/joc.2017.04.08

Traversari, R., Den Hoed, M., Di Giulio, R. and Bomhof, F. (2017). 'Towards sustainability through energy efficient buildings design: semantic labels', Entrepreneurship and Sustainability Issues, 4(3), 243-256. https://doi.org/10.9770/jesi.2017.4.3S(1)

Walancik, M., Chmiel, M. (2014). Security as a goal of the state existence-conditions and contexts based on the case of Poland. Forum Scientiae Oeconomia, 2(2), pp. 5-15)

Zeman, T., Břeň, J. and Urban, R. (2017). 'Role of Internet in Lone Wolf Terrorism', Journal of Security and Sustainability Issues, 7(2), 185-192. https://doi.org/10.9770/jssi.2017.7.2(1)

Zeman, T., Břeň, J., Urban, R. (2017). 'Role of Internet in Lone Wolf Terrorism', Journal of Security and Sustainability Issues, 7(2), 185-192. https://doi.org/10.9770/jssi.2017.7.2(1)

Zemlickiene, V., Mačiulis, A., Tvaronavičienè, M. (2017). 'Factors impacting the commercial potential of technologies: expert approach', Technological and Economic Development of Economy, 23(2), 410-427 http://dx.doi.org/10.3846/20294913.2016.1271061 